\title{
Characterization of a Novel Extremely Alkalophilic Bacterium
}

\author{
By KENNETH A. SOUZA AND PAUL H. DEAL \\ Biological Adaptation Branch, Ames Research Center, NASA, Moffett Field, \\ California 94035 U.S.A.
}

(Received I4 March 1977)

\begin{abstract}
A new alkalophilic bacterium, isolated from a natural spring of high $\mathrm{pH}$ is characterized. It is a Gram-positive, non-sporulating, motile rod requiring aerobic and alkaline conditions for growth. The characteristics of this organism resemble those of the coryneform group of bacteria; however, there are no accepted genera within this group with which this organism can be closely matched. Therefore, a new genus may be warranted.
\end{abstract}

\section{INTRODUCTION}

Of the few extremely alkalophilic bacteria which have been isolated and characterized, most are members of the genus Bacillus. Vedder (1934) was the first to report the isolation and cultivation of an alkalophilic micro-organism which he named Bacillus alcalophilus. More recently, Boyer, Ingle \& Mercer (1973) isolated from sewage a subspecies of this organism, B. alcalophilus subsp. halodurans. Other alkalophilic members of the genus Bacillus have also been described (Ohta et al., 1975; Chislett \& Kushner, 196r ; Horikoshi, 1971 $a, b$, 1972; Yamamoto, Tanaka \& Horikoshi, 1972). In this paper, we report the characterization of an extreme alkalophile, previously isolated from natural waters of high $\mathrm{pH}$, which does not appear to be a member of the genus Bacillus.

\section{METHODS}

Bacterial strains. Strain A-I was isolated from an alkaline spring located in Stanislaus County, California, U.S.A. The isolation procedure, location and mineral content of the spring have been reported by Souza et al. (1974). Escherichia coli and Bacillus subtilis were obtained from the culture collection of San Jose State University, San Jose, California, U.S.A. Other strains used were Bacillus alcalophilus ATCC27647 and B. alcalophilus subsp. halodurans ATCC27557.

Growth conditions. Growth rates were determined using cultures grown in I \% (w/v) Tryptic Soy Broth (Difco) with stirring at $27{ }^{\circ} \mathrm{C}$ and with the $\mathrm{pH}$ maintained with a Corning model Io $\mathrm{C}$ pH controller. Both absorbance at $450 \mathrm{~nm}$ and colony counts were used to measure growth rates. Tryptic Soy Agar (TSA) contained $10 \mathrm{~g}$ Tryptic Soy Broth (TSB) and $\mathrm{I} 5 \mathrm{~g}$ agar per litre distilled water. After autoclaving the medium, a filter-sterilized solution of $10 \%(\mathrm{w} / \mathrm{v}) \mathrm{NaHCO}_{3}$ was added to give a final concentration of $\mathrm{I} \%$. The desired $\mathrm{pH}$ was obtained by adding sterile $5 \mathrm{M}-\mathrm{NaOH}$. Bacterial stocks were lyophilized or maintained as frozen broth cultures and in both cases were stored at $-15{ }^{\circ} \mathrm{C}$. Strain A-I did not store well on TSA slants at either room temperature or $4{ }^{\circ} \mathrm{C}$. Attempts to demonstrate spores in strain A-r were made by cultivation on TSA, Sporulating Agar (Difco), TAM Sporulating Agar (Difco) and AK-2 Sporulating Agar (BBL). Each medium was adjusted to $\mathrm{pH} 8.5,9.0$ or 10.5 with $5 \mathrm{M}-\mathrm{NaOH}$, inoculated with a suspension of cells and incubated at $15{ }^{\circ} \mathrm{C}$ for 30 days. A duplicate set of plates was incubated at $30{ }^{\circ} \mathrm{C}$. Samples from the surface of all plates were periodically observed by phase contrast microscopy.

Biochemical tests. Production of acid and gas from carbohydrates was determined in medium containing (g per litre distilled water): peptone, $\mathrm{I} \cdot 2$; Nutrient Broth (Difco), $0.8 ; \mathrm{NaCl}, 5 \cdot 0 ;$ and $\mathrm{K}_{2} \mathrm{HPO}_{4}, 0.3$. The pH was adjusted to 10.5 with $1 \mathrm{M}-\mathrm{NaOH}, 10 \mathrm{ml}$ quantities were dispensed in tubes and Durham tubes were inserted. Carbohydrates, and glycerol, were each tested at a final concentration of $10 \mathrm{mg} \mathrm{ml}^{-1}$. The decrease in $\mathrm{pH}$ relative to cultures lacking the carbohydrate was measured after 5 and Io days incubation at $30^{\circ} \mathrm{C}$. 
Standard methods (Conn, 1957; Cowan \& Steel, 1965; Edwards \& Ewing, 1969) were used for the detection of indole, $\mathrm{H}_{2} \mathrm{~S}$, acetoin, nitrate reduction, catalase, and gelatin or starch hydrolysis. $\mathrm{NaHCO}_{3}$ interfered with the last three tests and was omitted from the solid medium. Oxidase was tested by the method of Kovacs (1956). The minimal medium of Gordon \& Mihm (1957) was used to determine the ability of bacteria to use organic acids or carbohydrates at $20 \mathrm{~g} \mathrm{l}^{-1}$ as sole sources of carbon and energy. The medium was adjusted to $\mathrm{pH} 10.5$ with $5 \mathrm{M}-\mathrm{NaOH}$ and buffered with $\mathrm{NaHCO}_{3}$ at a final concentration of $\mathrm{I} \%$.

DNA base ratio. DNA was extracted from cells by the method of Marmur (1961) and the mol $\%$ GC was determined by the thermal denaturation method (Marmur \& Doty, 1962).

Antibiotic sensitivity. The ability of strain A-I to grow in the presence of antibiotics was determined by inoculating tubes containing $\mathrm{I} \% \mathrm{TSB}, \mathrm{I} \% \mathrm{NaHCO}_{3}$ and one of the following antibiotics at a final concentration of $10 \mu \mathrm{g} \mathrm{ml}^{-1}$ : bacitracin, chloramphenicol, penicillin, polymyxin $\mathbf{B}$, streptomycin and tetracycline. The medium was adjusted to $\mathrm{pH} 10 \cdot 0$ with sterile $5 \mathrm{M}-\mathrm{NaOH}$ and incubated at $30^{\circ} \mathrm{C}$. Growth was defined as the appearance of visible turbidity within 30 days.

Electron microscopy. Methods used to demonstrate flagellar arrangement and cell-wall structure were those of Souza et al. (1974).

Intracellular $\mathrm{pH}$. Strain A-I was grown in $311 \% \mathrm{TSB}$ at pH 10.5 in a rotary shaker-bath at $30^{\circ} \mathrm{C}$. Bacteria were harvested in the late-exponential phase of growth by centrifuging at $\mathrm{I} 2000 \mathrm{~g}$ for $10 \mathrm{~min}$ at $4{ }^{\circ} \mathrm{C}$, washed twice in $150 \mathrm{ml}$ water adjusted to $\mathrm{pH} 10.5$ with $0.0 \mathrm{I} \mathrm{M}-\mathrm{NaOH}$, and finally resuspended in $10 \mathrm{ml}$ water at $\mathrm{pH} 7 \cdot 0$. Cells were broken in a French press at $140 \mathrm{MPa}$ and the $\mathrm{pH}$ of the lysate was recorded. The procedure was repeated using water of $\mathrm{pH} 6.5,7.5$ or 8.0 for the final resuspension and rupture of the cells: this was done to confirm that when cells were broken in water of $\mathrm{pH}$ above the intracellular $\mathrm{pH}$, the $\mathrm{pH}$ of the lysate was lowered and that when cells were broken in water of $\mathrm{pH}$ below the intracellular $\mathrm{pH}$, the $\mathrm{pH}$ of the lysate was raised. Cells were also ruptured by sonication (several $15 \mathrm{~s}$ exposures at the maximum intensity of a Biosonik III sonicator, Bronwill Scientific Co., Rochester, New York, U.S.A.; 4 mm probe), and by treatment with lysozyme $\left(\mathrm{I} \cdot 0 \mathrm{mg} \mathrm{ml}{ }^{-1}\right)$ for $15 \mathrm{~min}$ at $30^{\circ} \mathrm{C}$.

\section{RESULTS}

\section{Growth characteristics}

Strain A-I required alkaline and aerobic conditions to grow. It grew in I \% TSB at $\mathrm{pH} 8.0$ and II 4 with average generation times of 180 and $560 \mathrm{~min}$, respectively. The optimum $\mathrm{pH}$ for growth was between 9.0 and 9.5 as indicated by the minimum time required to double the cell mass $\left(72 \mathrm{~min}\right.$ at $27^{\circ} \mathrm{C}$ ). Growth and division did not occur in broth cultures at either $\mathrm{pH} 7.5$ or $\mathrm{II} \cdot 6$. Bacteria grown in $\mathrm{I} \% \mathrm{TSB}$ at $\mathrm{pH} 10.5$ had an optimum growth temperature of $37^{\circ} \mathrm{C}$ with a generation time of $80 \mathrm{~min}$ and a maximum temperature for growth between 42 and $44{ }^{\circ} \mathrm{C}$.

Numerous attempts were made to grow strain A-I anaerobically but no growth was obtained on a variety of media, including Nitrate Broth (Difco), and over a range of alkalinities. However, it did grow very slowly in static cultures, indicating that it does not require highly aerobic conditions for growth.

\section{Morphology}

Cell morphology varied with the $\mathrm{pH}$ of the growth medium. At the extremes of the growth range, the cells formed convoluted filaments, whilst at a $\mathrm{pH}$ near optimum, cells grew as paired or single, straight rods approximately $2 \cdot 3 \times 0.6 \mu \mathrm{m}$ (Fig. I). Cells were motile except at the extremes of $\mathrm{pH}$, and flagella were peritrichous (Fig. 2). Numerous mesosomal-like structures were observed within the cells which may account for the granular appearance of stained cells, particularly in old cultures.

Strain A-I did not yield a consistent Gram's stain reaction by conventional methods (Skerman, 1959). Crystal violet was lost rather easily, resulting in either a predominance of Gram-negative bacteria interspersed with some Gram-positive bacteria, or Gramnegative bacteria with Gram-positive inclusions within the cell. The more sensitive Kopeloff and Beerman modification of Gram's stain (Conn, Bartholomew \& Jennison, 1957) gave a higher proportion of Gram-positive bacteria per field but a definite conclusion could not be reached. Electron microscopy of thin sections of strain A-I revealed the thick amorphous 

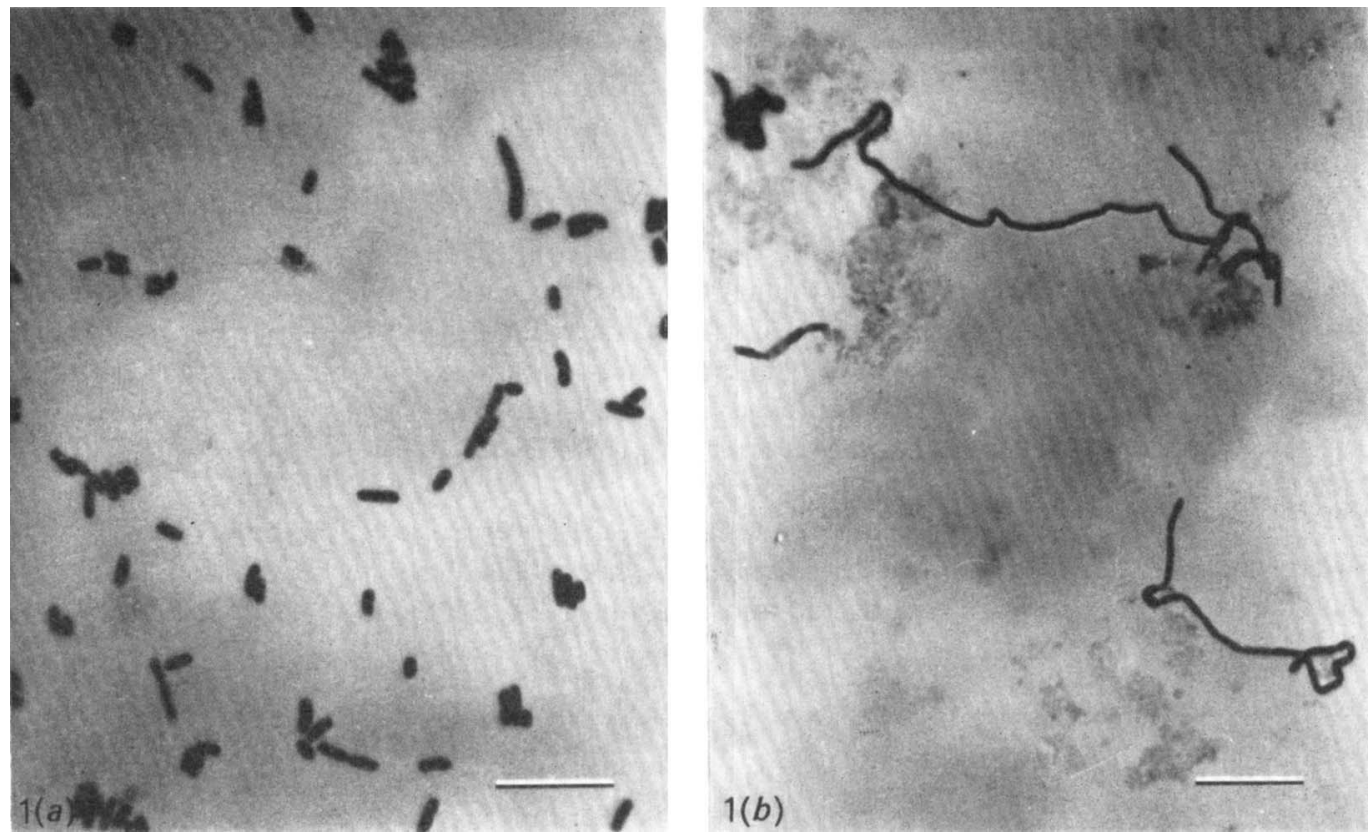

Fig. I. Phase contrast photomicrographs of strain A-I grown in $1 \%$ Tryptic Soy Broth at $(a) \mathrm{pH} 9.5$ and (b) $\mathrm{pH}$ I I 2 . Bar markers represent $10 \mu \mathrm{m}$.
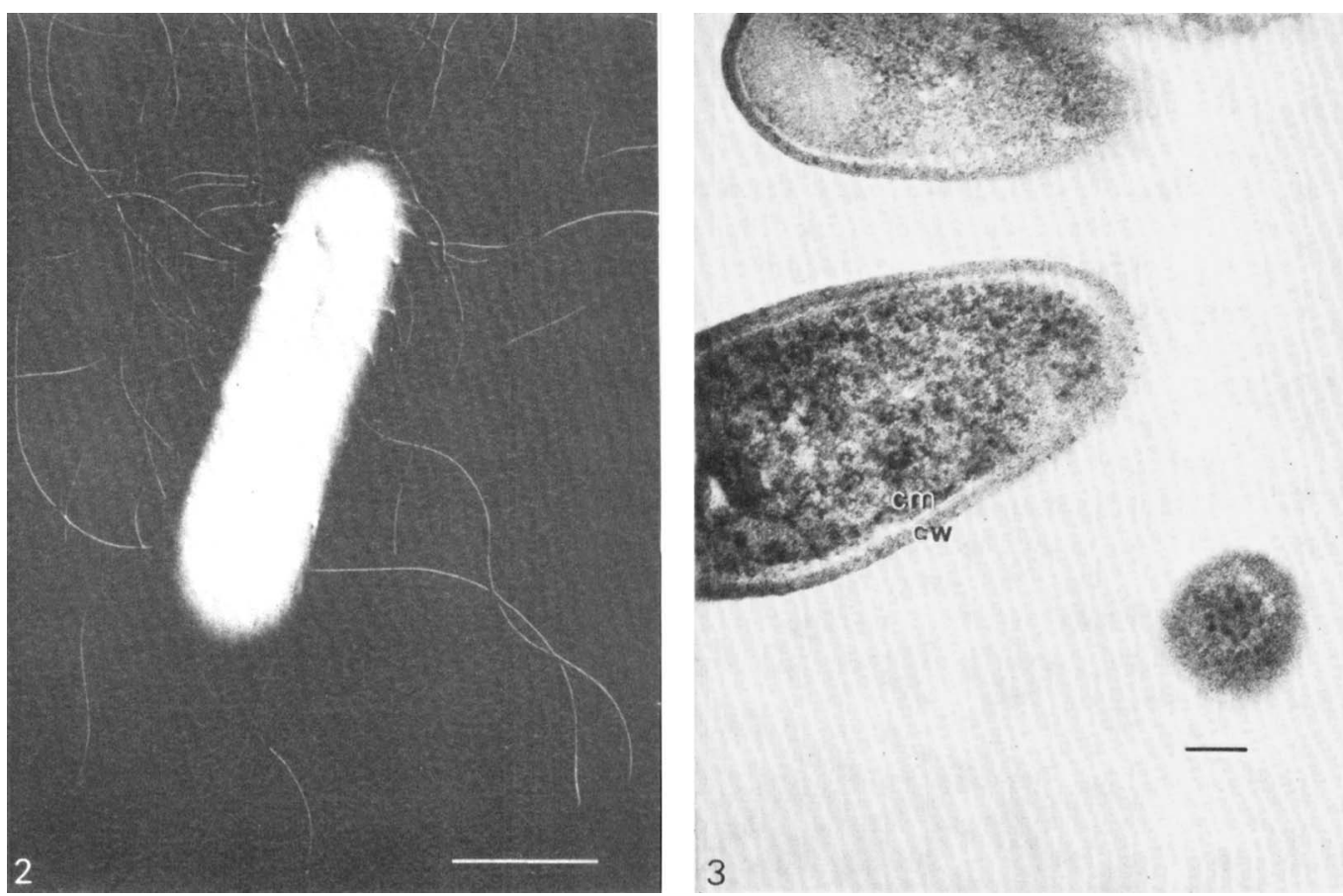

Fig. 2. Peritrichous arrangement of flagella on a bacterium taken from an exponentially growing culture of strain A- $\mathrm{I}$ in $\mathrm{I} \%$ Tryptic Soy Broth at pH 9.5. Bar marker represents $0.5 \mu \mathrm{m}$.

Fig. 3. Thin sections of strain A-I which reveal the cell-wall (cw) thickness and structure. The cell membrane $(\mathrm{cm})$ can also be seen. Bar marker represents $0 \cdot I \mu \mathrm{m}$. 
cell wall typical of Gram-positive bacteria (Reynolds, I973), and measurements of numerous thin sections of several specimens indicated a wall thickness between 22 and $30 \mathrm{~nm}$ (Fig. 3).

Colonies formed on I \% TSA at $30{ }^{\circ} \mathrm{C}$ were uniformly round, convex, had entire margins and were I to $3 \mathrm{~mm}$ diam. They were opaque and initially colourless, but became yelloworange within several days.

\section{Pigments}

The yellow-orange pigment of strain A-I did not diffuse into the media nor did the colonies fluoresce in ultraviolet light. Pigmentation varied with cultural conditions: colonies on TSA, pH 10.5 , became bright yellow-orange after 2 to 3 days at $30^{\circ} \mathrm{C}$, whereas colonies on Potato Dextrose Agar (Difco) developed a much darker orange hue on similar incubation. Packed cells, harvested by centrifugation from I \% TSB at $\mathrm{pH} 8.5$ to $\mathrm{I} 0.5$ appeared yelloworange, whereas packed cells harvested from $\mathrm{I} \% \mathrm{TSB}$ above $\mathrm{pH} 10.5$ were yellow and at $\mathrm{pH}$ I I 4 , they were nearly white.

Pigments extracted with chloroform/methanol (2:, $\mathrm{v} / \mathrm{v})$ from cells grown at $\mathrm{pH} 10.5$, dried under $\mathrm{N}_{2}$ and resuspended in petroleum spirit or hexane, had absorption maxima at 429 and $45 \mathrm{I} \mathrm{nm}$ and shoulders at 409 and $480 \mathrm{~nm}$. This spectrum suggests the presence of carotenoid compounds.

\section{Biochemical characteristics}

Acid, but no gas, was produced from L-arabinose, D-fructose, D-galactose, D-glucose, lactose, maltose, D-mannitol, salicin, D-sorbitol, sucrose and D-xylose. Strain A-I did not produce acid or gas from glycerol. Starch, casein and gelatin were hydrolysed. Catalase and oxidase tests were positive. Acetoin, indole and $\mathrm{H}_{2} \mathrm{~S}$ were not produced. Nitrate was not reduced to nitrite and citrate was not utilized. No growth occurred in the minimal medium of Gordon \& Mihm (I957) with sodium acetate, sucrose, D-xylose, D-glucose, sodium lactate or sodium succinate supplied as sole sources of carbon and energy. However, in the medium used to measure acid and gas production, which differs most notably from that of Gordon \& Mihm by the inclusion of peptone and nutrient broth, strain A-I utilized both glucose and sucrose and also grew in the same medium without any added carbohydrate. Thus, the lack of growth in the medium of Gordon \& Mihm (1957) may be due to the lack of protein supplement or other growth requirement contained in the peptone and/or nutrient broth of the more complex medium.

Thermal denaturation experiments with strain A-I DNA yielded the typical hyperchromic shift of double-stranded DNA and a GC content of $46.4 \mathrm{~mol} \%$, as calculated by the method of Marmur \& Doty (I962).

Strain A-I grew over a wide range of $\mathrm{NaCl}$ concentrations. Good growth was obtained at $\mathrm{pH} 10.5$ in media containing $\mathrm{I} \%(\mathrm{w} / \mathrm{v})$ nutrient broth, $\mathrm{I} \%(\mathrm{w} / \mathrm{v})$ glucose and $\mathrm{NaCl}$ at 0,5 or $7 \%$ (w/v). Slow growth also occurred in $9 \% \mathrm{NaCl}$ but no growth occurred in 12 or $15 \%$ $\mathrm{NaCl}$ after 20 days incubation at $30{ }^{\circ} \mathrm{C}$. No spores were observed in bacterial suspensions prepared from growth on a variety of solid and liquid media at the temperatures and incubation periods used. Growth was not inhibited by penicillin, streptomycin, tetracycline, bacitracin or polymyxin $\mathrm{B}$ at $10 \mu \mathrm{g} \mathrm{ml}^{-1}$ but was inhibited by the same concentration of chloramphenicol.

\section{Intracellular $\mathrm{pH}$}

The intracellular $\mathrm{pH}$ was determined after disrupting the bacteria with lysozyme, by sonication or in a French pressure cell; the values were between $7 \cdot 4$ and $7 \cdot 7$ (Table I). The intracellular $\mathrm{pH}$ values of three non-alkalophilic organisms, E. coli, B. subtilis and an unclassified rod designated BSA, were also determined and all were below that of strain A-I (Table I). 
Table I. Determination of intracellular $p H$

$\begin{array}{lccc} & & & \text { Intracellular } \\ \text { Organism } & \text { Growth pH } & \text { Method of rupture } & \mathrm{pH} \\ \text { Strain A-I } & 10 \cdot 0 & \text { French press } & 7.7 \\ & 10 \cdot 0 & \text { Sonication } & 7.5 \\ & 10 \cdot 0 & \text { Lysozyme } & 7.4 \\ \text { E. coli } & 7 \cdot 0 & \text { French press } & 6.8 \\ \text { B. subtilis } & 7 \cdot 0 & \text { French press } & 6.9 \\ \text { Strain BSA } & 7.0 & \text { French press } & 6.9\end{array}$

Table 2. Differentiation of strain A-I, Bacillus alcalophilus and B. alcalophilus subsp. halodurans

\begin{tabular}{|c|c|c|c|}
\hline Characteristic & Strain A-I & B. alcalophilus & $\begin{array}{l}\text { B. alcalophilus } \\
\text { subsp. } \\
\text { halodurans }\end{array}$ \\
\hline Casein hydrolysis & + & \pm & + \\
\hline Gelatin hydrolysis & + & \pm & + \\
\hline Anaerobic growth & - & + & + \\
\hline Spores produced & - & + & + \\
\hline $\begin{array}{l}\text { Maximum temperature }\left({ }^{\circ} \mathrm{C}\right) \text { for } \\
\text { aerobic growth at } \mathrm{pH} \text { 10.5 }\end{array}$ & $42-44$ & $40-42$ & $50-54$ \\
\hline Nitrate reduction & - & - & + \\
\hline Citrate utilization & - & - & + \\
\hline Orange pigmentation & + & - & - \\
\hline GC content ( $\mathrm{mol} \%)$ & 46 & 40 & 47 \\
\hline Growth in $\mathrm{NaCl}(\%, \mathrm{w} / \mathrm{v}): 0$ & + & + & + \\
\hline 5 & + & \pm & + \\
\hline 7 & + & - & + \\
\hline 9 & + & - & + \\
\hline 12 & - & - & + \\
\hline 15 & - & - & + \\
\hline
\end{tabular}

Differentiation of strain $\mathrm{A}-\mathrm{I}$ and B. alcalophilus

Although we could not demonstrate endospores in strain A-I it was still possible that this organism could be related to alkalophilic members of the genus Bacillus. For this reason $B$. alcalophilus and B. alcalophilus subsp. halodurans were compared with strain A-I. The tests selected for this purpose were based on the extensive characterization of $B$. alcalophilus and $B$. alcalophilus subsp. halodurans by Boyer et al. (1973). The results (Table 2) indicated that strain A-I could easily be differentiated from B. alcalophilus and B. alcalophilus subsp. halodurans on the basis of anaerobic growth, sporulation, pigment production and salt tolerance. It could be further differentiated from $B$. alcalophilus by the GC content of its DNA, and from $B$. alcalophilus subsp. halodurans by a lower maximum growth temperature and failure to reduce nitrate or utilize citrate. The GC contents of strain A-I and B. alcalophilus subsp. halodurans were similar, but DNA hybridization experiments will be required before the significance of this relationship can be evaluated.

\section{DISCUSSION}

The eighth edition of Bergey's Manual of Determinative Bacteriology (Buchanan \& Gibbons, 1974) includes four genera of asporogenous Gram-positive bacteria to which strain A-I bears some resemblance: Brevibacterium, Kurthia, Corynebacterium and Listeria. 
Brevibacterium is described as typically short unbranched rods, reproducing by simple cell division. Some species may produce red, orange, yellow or brown water-insoluble pigments. Species are aerobic or facultative anaerobic and, when motile, are peritrichously flagellated. The GC content of the DNA of Brevibacterium species varies from 46.6 to $70.5 \mathrm{~mol} \%$. Strain A-I is also a short unbranched rod which reproduces by simple cell division. It produces a water-insoluble yellow-orange pigment, is aerobic, is peritrichously flagellated, and the GC content of its DNA is $46.4 \mathrm{~mol} \%$. Thus, strain A-I could be considered a species of Brevibacterium, except that Brevibacterium is no longer accepted as a valid genus according to the eighth edition of Bergey's Manual and has been classified as a genus incertae sedis. Therefore, strain A-I cannot properly be placed within this genus.

The genus Kurthia contains only one accepted species, $K$. zopfii, which is described as a rod, $0.8 \times 3$ to $4 \mu \mathrm{m}$, and motile by peritrichous flagella although non-motile strains may occur. Gelatin and starch are not hydrolysed, pigment is generally not synthesized, and no acid is produced from carbohydrates. It is a strict aerobe using molecular oxygen as the terminal electron acceptor. Our results with strain A-I showed that, although similar to Kurthia in morphology, flagella arrangement and aerobic nature, it differed in that starch and gelatin are hydrolysed, pigment is synthesized and acid is produced from many carbohydrates.

Cornyebacterium species are typically non-motile and pathogenic, with a GC content between 50 and $70 \mathrm{~mol} \%$, although most species fall within the 57 to $60 \%$ range. Cell division is unusual and is characterized by snapping division which results in an angular and palisade arrangement of cells. Strain A-I, however, is motile and is not known to be pathogenic. It reproduces by simple binary fission and has a GC content of $46 \cdot 4 \mathrm{~mol} \%$. These differences indicate that strain A-I does not belong within the genus Corynebacterium.

The genus Listeria contains four species which are characterized as aerobic, small, peritrichously flagellated rods which are pathogenic to animals. Acid, but no gas, is usually produced from glucose and several other carbohydrates. Gelatin and casein are not hydrolysed and the species are all catalase-positive. Three of the four species have GC contents of $38 \mathrm{~mol} \%$ while the fourth, Listeria denitrificans, contains $56 \mathrm{~mol} \% \mathrm{GC}$. Unlike Listeria species, strain A-I produces acid from numerous carbohydrates, gelatin and casein are hydrolysed, and the GC content is $46.4 \mathrm{~mol} \%$.

Of the four genera mentioned above, three are members of the coryneform group of bacteria, Brevibacterium, Kurthia and Corynebacterium. Listeria is not included in this group, nor is it associated with any bacterial family, but instead is considered a genus of uncertain affiliation. Strain A-I could be related to the coryneform group of bacteria and perhaps could be considered a new alkalophilic species of one of the genera mentioned above. Additional work is required before a conclusion regarding its taxonomic position can be reached. For example, the cell walls of coryneform bacteria usually contain corynemycolic acids which are unique to this group of organisms. Detecting such acids in the walls of strain A-I would definitely link it to this group. Alternatively, the absence of such acids would warrant the consideration of a new genus, one which would contain asporogenous, Gram-positive, extremely alkalophilic aerobes such as strain A-I.

Alkalophilic bacteria have adapted to a unique ecological niche, although how these organisms grow and reproduce in such an environment remains unknown. Ohta et al. (1975) have recently demonstrated that several intracellular enzymes of an unidentified alkalophilic member of the genus Bacillus do not possess unusual alkali-stable properties. These enzymes (lactate, alanine and malate dehydrogenases) showed maximum activities at $\mathrm{pH}$ values between $7 \cdot 4$ and $8 \cdot 4$, similar to non-alkalophiles. In contrast, extracellular enzymes from alkalophilic bacilli are unusually alkali-stable and exhibit maximum activity at pH ro or above (Horikoshi, I97I $a, b, 1972$; Yamamoto et al., 1972). This difference in $\mathrm{pH}$ optima between intracellular and extracellular enzymes suggests that alkalophiles are able to maintain a nearly neutral internal environment in the presence of a high external $\mathrm{pH}$. 
Supporting this suggestion, the intracellular $\mathrm{pH}$ of strain A-I was only slightly higher than that of three non-alkalophiles we examined. Therefore, in alkalophilic organisms, intracellular metabolic processes would not have to be especially alkali-stable. Furthermore, we have assayed the activity of an intracellular enzyme, malate dehydrogenase, by determining the oxaloacetate-dependent reduction of $\mathrm{NADH}$, and, like Ohta et al. (1975), we observed that maximum activity occurred near $\mathrm{pH} 8$ and no activity could be demonstrated at $\mathrm{pH}$ ro or above (unpublished data). Undoubtedly, the cell membrane is involved in the regulation of the intracellular $\mathrm{pH}$, but the processes which accomplish this feat remain to be elucidated. It is our hope that strain $\mathrm{A}-\mathrm{I}$ will prove a useful tool in the elucidation of this problem.

\section{REFERENCES}

Boyer, E. W., INGle, M. B. \& Mercer, G. D. (1973). Bacillus alcalophilus subsp. halodurans subsp. nov.: an alkaline-amylase-producing, alkalophilic organism. International Journal of Systematic Bacteriology 23, 238-242.

Buchanan, R. E. \& Gibbons, N. E. (editors) (I974). Bergey's Manual of Determinative Bacteriology, 8th edn. Baltimore: Williams \& Wilkins.

Chislett, M. E. \& Kushner, D. J. (I96I). A strain of Bacillus circulans capable of growing under highly alkaline conditions. Journal of General Microbiology 24, 187-190.

ConN, H. J. (1957). Manual of Microbiological Methods. New York: McGraw-Hill.

ConN, H. J., BartholomeW, J. W. \& Jennison, M. W. (I957). Staining methods. In Manual of Microbiological Methods, p. I7. Edited by H. J. Conn. New York: McGraw-Hill.

CowAN, S. T. \& STEEL, K. J. (1965). Manual for the Identification of Medical Bacteria. London and New York: Cambridge University Press.

EDWARDs, P. R. \& EWING, W. H. (I969). Identification of Enterobacteriaceae. Minneapolis: Burgess Publishing Co.

Gordon, R. E. \& Mrhm, J. M. (I957). A comparative study of some strains received as Nocardiae. Journal of Bacteriology 73, I 5-27.

Horikoshi, K. (I97I $a$ ). Production of alkaline enzymes by alkalophilic microorganisms, Part $\mathbf{I}$. Alkaline protease produced by Bacillus no. $22 \mathrm{r}$. Agricultural and Biological Chemistry 35, $1407^{-}$ I4I 4 .

Horikoshi, K. (I97 I $b$ ). Production of alkaline enzymes by alkalophilic microorganisms, Part II. Alkaline amylase produced by Bacillus no. A-40-2. Agricultural and Biological Chemistry 35, 1783I79I.

HoRIKOSHI, K. (I972). Production of alkaline enzymes by alkalophilic microorganisms, Part III. Alkaline pectinase of Bacillus P-4-N. Agricultural and Biological Chemistry 36, 285-293.

Kovacs, N. (1956). Identification of Pseudomonas pyocyanea by the oxidase reaction. Nature, London $\mathbf{1 7 8 , 7 0 3 . ~}$

MARMur, J. (196I). A procedure for the isolation of deoxyribonucleic acid from micro-organisms. Journal of Molecular Biology 3, 208-2 I 8.

MARmur, J. \& Doty, P. (I962). Determination of the base composition of deoxyribonucleic acid from its thermal denaturation temperature. Journal of Molecular Biology 5, I09-I18.

Ohta, K., Kiyomiya, A., Koyama, N. \& Nosoh, Y. (1975). The basis of the alkalophilic property of a species of Bacillus. Journal of General Microbiology 86, 259-266.

REYNoLDS, P.E. (I973). The bacterial cell: major structures. In Biochemistry of Bacterial Growth, 2nd edn, pp. 63-136. Edited by J. Mandelstam and K. McQuillen. New York: John Wiley.

SKerman, V. B. D. (1959). A Guide to the Identification of the Genera of Bacteria. Baltimore: Williams \& Wilkins.

Souza, K. A., Deal, P. H., Mack, H. M. \& Turnbill, C. E. (1974). Growth and reproduction of microorganisms under extremely alkaline conditions. Applied Microbiology 28, I066-I068.

VEDDER, A. (1934). Bacillus alcalophilus sp. nov.; benevens enkle ervaringen met sterk alcalische voedingsbodems. Antonie van Leeuwenhoek r, I 4 I-I 47 .

Yamamoto, M., TANaKa, Y. \& HoRikoshi, K. (1972). Production of alkaline enzymes by alkalophilic microorganisms, Part IV. Alkaline amylases of alkalophilic bacteria. Agricultural and Biological Chemistry 36, 1819-1823. 